\title{
Comparison of the postoperative analgesic efficacy of an ultrasound-guided fascia iliaca compartment block versus 3 in 1 block in hip prosthesis surgery
}

\author{
Kalça protez operasyonlarnda ultrasonografi rehberliğinde gerçekleştirilen \\ fasia iliaka kompartman bloğu ile 3-1 bloğun ameliyat sonrası \\ analjezik etkinliğinin karşılaştırılması
}

\author{
Süleyman DENIZ, ${ }^{1}$ Abdulkadir ATIM, ${ }^{1}$ Mustafa KÜRKLÜ, ${ }^{2}$ Tuncer ÇAYCl, ${ }^{3}$ Ercan KURT ${ }^{1}$
}

\begin{abstract}
Summary
Objectives: In this study, we aimed to compare the postoperative analgesic efficiency of an ultrasound-guided fascia iliaca compartment block and a 3 in 1 block in patients who underwent hip prosthesis surgery as a result of hip fracture.

Methods: With approval from the local ethics committee, 70 patients, aged 20 to 80 , undergoing hip prosthesis surgery under elective conditions were included in this randomized, prospective, controlled study. They were informed of the patientcontrolled analgesia (PCA) device and visual analog scale (VAS). All patients were separated randomly into three groups. Anaesthesia induction was standardized for all groups. An ultrasound guidance fascia iliaca compartment block (FICB) was applied to the first group before anaesthesia induction. For the second group, a 3 in 1 block was applied, while for the control group no block was applied. After incision on all patients, $20 \mathrm{mg}$ tenoxicam and $1 \mathrm{mg} / \mathrm{kg}$ tramadol were injected intravenously. Following surgery, IV tramadol PCA was begun on all patients routinely. In our study, the presence of cortisol and ACTH levels, hemodinamical parameters, nausea and sedation were determined.

Results: We observed a decrease in VAS values and opioid consumption, no adverse effects on nausea and sedation, and a suppression of stress hormones in both the ultrasound-guided FICB and 3 in 1 block groups.

Conclusion: We believe that the safe and efficient application of the ultrasound-guided 3 in 1 block and the FICB is necessary in multimodal analgesic treatment in order to enable postoperative analgesia in hip prosthesis surgery.
\end{abstract}

Key words: 3 in 1 block; fascia iliaca compartment block; Hip prosthesis; postoperative analgesia; ultrasound.

\section{Özet}

Amaç: Bu çalışmada, kalça kırı̆̆ı sonucu kalça protezi ameliyatı geçirecek hastalarda ultrason rebberliğinde fasiya iliyaka kompartman bloğu ve 3-1 bloğun ameliyat sonrası analjezik etkinliğini karşılaştırmayı amaçladık.

Gereç ve Yöntem: Elektif şartlarda kalça protezi ameliyatı olacak, 20 ve 80 yaş arası 70 basta, yerel etik komite onayını aldıktan sonra bu randomize, ileriye yönelik, kontrollü çalışmaya dabil edildi. PCA ve vizüel analog skala (VAS) bakkında bilgi verildi. Tüm hastalar rastgele üç gruba ayrıldı. Anestezi indüksiyonu tüm gruplar için standardize edildi. Ultrason rebberliğinde fasiya iliyaka kompartman bloğu (FICB) ilk gruba ve 3-1 blok ise ikinci gruba anestezi indüksiyonu öncesi uygulandı. Kontrol grubu için bir blokaj uygulanmadı. Tüm hastalara cerrabi kesi sonrası $20 \mathrm{mg}$ tenoksikam ve $1 \mathrm{mg} / \mathrm{kg}$ tramadol intravenöz yoldan enjekte edildi. Ameliyat sonrasında IV tramadol hasta kontrollü analjezi (PCA) rutin olarak tüm bastalara başlandı. Çalışmamızda Kortizol ve ACTH düzeyleri, hemodinamik parametreler, bulantı ve sedasyon varliğı araştırıldı.

Bulgular: Çalısmamızda ultrason rebberliğinde uygulanan FICB ve 3-1 bloğun kontrol grubuna göre, VAS değerleri ve opioid tüketimini azalttı̆̆ını, bulantı ve sedasyon üzerine hiçbir yan etkisinin olmadığını ve stres hormonlarını baskıladığını tespit ettik.

Sonuç: Kalça protez operasyonlarında ultrason eşliğinde uygulanan 3-1 blok ve FICB’nin ameliyat sonrası analjezi sağlamak amacıyla multimodal analjezik tedavinin bir parçası olması ve bu yöntemlerin güvenli bir yol olarak belirtilmesi gerektiğine inanmaktayız.

Anahtar sözcükler: 3-1 blok; fasiya iliyaka kompartman bloğu; kalça protezi; ameliyat sonrası analjezi; ultrason.

\footnotetext{
'Department of Anesthesiology and Reanimation, Gulhane Military Faculty of Medicine, Ankara, Turkey; ${ }^{2}$ Department of Orthopedics and Traumatology, Gulhane Military Faculty of Medicine, Ankara, Turkey; ${ }^{3}$ Department of Biochemistry, Gulhane Military Faculty of Medicine, Ankara, Turkey 'Gülhane Askeri Tıp Akademisi, Anesteziyoloji ve Reanimasyon Anabilim Dall, Ankara; ${ }^{2}$ Gülhane Askeri Tıp Akademisi, Ortopedi ve Travmatoloji Anabilim Dalı, Ankara; 3Gülhane Askeri Tıp Akademisi, Biyokimya Anabilim Dalı, Ankara
} 


\section{Introduction}

Hip fracture is a common fracture type in the adult population. It is an issue which occupies hospital beds mostly and has high mortality rate. ${ }^{[1]}$

Patients who will undergo total hip prosthesis (THP) are usually elderly and have limited cardiac and pulmonary reserve. Severe pain is usually present in the postoperative period. In addition, the sensitivity to drugs and their adverse effects is increased in these patients. Thus, postoperative analgesia is ideally provided with drugs and methods which have fewer adverse effects and better tolerance. ${ }^{[2,3]}$

Lumbar plexus block provides high quality analgesia after hip, femoral shaft and knee surgery, ${ }^{[4-6]}$ and is superior to systemic morphine administration and has less adverse effects compared to epidural anesthesia. ${ }^{[4,7-8]}$

Although several approaches have been described related to lumbar plexus block, Winnie et al. ${ }^{[9]}$ described a method (3 in 1 block) which allows block of the femoral nerve with only one injection of 20 $\mathrm{ml}$ of local anesthetic.

A neural blockade technique which was discovered unexpectedly during blockage of lateral femoral cutaneous nerve, and evaluation of anatomic configuration of fascia iliaca which surrounds femoral nerve and its branches led to identification of fascia iliaca compartment block (FICB). ${ }^{[4,5]}$

In several studies spearheaded by Swenson ${ }^{[10,11]}$ and Dolan, ${ }^{[12]}$ FICB was successfully performed with guidance of ultrasound.

In this study, we aimed to compare postoperative analgesic efficiency of ultrasound-guided fascia iliaca compartment block and 3 in 1 block in patients who underwent hip prosthesis surgery as a result of hip fracture.

\section{Materials and Methods}

After having the approval of local ethics committee, 70 patients, aged between 20 and 80, undergoing hip prosthesis surgery under elective conditions was included to this randomized, prospective, controlled study.
The patients were informed about study and their verbal and written approvals were obtained (The first anesthesiologist: SD).

Patients with at least one of the conditions below were excluded from the study: spinal or epidural anesthesia, ASA IV or above, weight below $40 \mathrm{kgs}$ or above $125 \mathrm{kgs}$, inguinal or femoral hernia, allergy to local anesthetics, peripheral neuropathy, neurologic deficit or abnormal coagulation profile, mental retardation, dementia, insufficient understanding of pain scoring systems and use of patient controlled analgesia (PCA) device.

\section{Procedure (The second anesthesiologist: EK)}

All patients were informed about PCA device and visual analog scale (VAS) before the procedure. VAS value was formed by patients marking on a horizontal line which no pain is shown as " 0 " and the most severe pain is shown as " 10 ".

Vascular access was obtained before the procedure and patients were sedated with $0,03 \mathrm{mg} \mathrm{kg}^{-1} \mathrm{IV}$ midazolam. $10 \mathrm{ml} \mathrm{kg}{ }^{-1} \mathrm{~h}-10.9 \%$ saline infusion was infused for hydration. All patients were taken to operating room in the supine position. Routine monitoring was applied including standard heart rate (HR), electrocardiography (ECG), noninvasive mean arterial pressure (MAP) and peripheral oxygen saturation $\left(\mathrm{SPO}_{2}\right)$.

All patients were separated into three groups randomly.

-1st Group: FICB group (n=24)

- 2nd Group: 3 in 1 block group $(\mathrm{n}=24)$

-3rd Group: Control group ( $\mathrm{n}=22)$

\section{FICB group}

The linear probe (12L-RS, 7-11 MHz) of LOGİQ Book XP Ultrasound (GE Medical systems, Solingen, Deutschland) used. 30 minutes before the surgery, after asepsis, following local anesthesia with $2 \%$ prilocaine, $30 \mathrm{ml}$ of $0.25 \%$ bupivacaine $\left(1 \mathrm{mg} \mathrm{kg}^{-1}\right)$ was injected after passing fascia iliaca with $50 \mathrm{~mm} / 22 \mathrm{G}$ blunt-ended peripheral nerve stimulator (Plexivygon, Vygon ${ }^{\oplus}$, France) needle. The spread of local anesthetic was followed with ultrasound. Then standard general anesthesia was performed. 


\section{3 in 1block group}

The linear probe used. 30 minutes before the surgery, after asepsis, following local anesthesia with $2 \%$ prilocaine $1 \mathrm{~cm}$ lateral of femoral artery, $30 \mathrm{ml}$ of $0.25 \%$ bupivacaine $\left(1 \mathrm{mg} \mathrm{kg}^{-1}\right)$ was applied with $50 \mathrm{~mm} / 22 \mathrm{G}$ blunt-ended peripheral nerve stimulator needle. Continuous contractions with values of $0.5 \mathrm{~mA}$ of the quadriceps femoris muscle were accepted as optimal needle position. The spread of local anesthetic was followed with ultrasound. Then standard general anesthesia was performed.

\section{Control group}

Standard general anesthesia was performed to this group without nerve block.

\section{Test blocks (The third anesthesiologist: AA)}

Femoral, obturatory and lateral femoral cutaneous nerve dermatomes were assessed for sensory block with pin-prick test by using a blunt-ended needle before general anesthesia at all patients who received neural blockade. Conditions with complete blockage at all three target nerve distribution areas or complete blockage at two target nerve distribution areas and above $80 \%$ blockage of the other target nerve distribution area were accepted as successful block. $^{[4]}$

\section{Intraoperative management}

\section{(The first anesthesiologist: SD)}

Fentanyl $1 \mu \mathrm{g} \mathrm{kg}^{-1}$, vecuronium bromide $0.1 \mathrm{mg} \mathrm{kg-}$ 1, and propofol 2-3 mg kg-1 were used for standard general anesthesia. Maintenance was provided with vecuronium bromide $0.02 \mathrm{mg} \mathrm{kg}^{-1}, 1.5-2 \%$ sevoflurane, and $50 \% \mathrm{~N}_{2} \mathrm{O}-\mathrm{O}_{2}$ mixture as $4 \mathrm{~L} \mathrm{~min}^{-1}$. After incision, $20 \mathrm{mg}$ tenoxicam and $1 \mathrm{mg} \mathrm{kg}^{-1}$ tramadol was given IV. After the surgery, neuromuscular blockade was reversed with $0.03 \mathrm{mg} \mathrm{kg}^{-1} \mathrm{IV}$ neostigmine and $0.01 \mathrm{mg} \mathrm{kg}^{-1} \mathrm{IV}$ atropine, and then patients were extubated and taken to post-anesthesia care unit (PACU). Prophylactic antiemetic was not applied.

PCA device (Abbott, Pain management provider, North Chicago, ABD) was prepared with tramadol $5 \mathrm{mg} \mathrm{ml}^{-1}$ concentration, $20 \mathrm{mg}$ of bolus, 30 minutes of lock time, $150 \mathrm{mg}$ limit for 4 hours and total dose of $500 \mathrm{mg}$ was supplied to all patient groups as standard.

\section{Preoperative/intraoperative evaluation (The first anesthesiologist: SD)}

$\mathrm{HR}$ and MAP values at pre-induction, induction, incision, 5th, 15th, 30th and 60th minutes were recorded in this section.

\section{Postoperative evaluation \\ (The first anesthesiologist: SD)}

VAS values, nausea score, sedation score and tramadol consumption at postoperative $0,2 \mathrm{nd}, 4 \mathrm{th}$, 6th and 24th hours were recorded in this section. Patients were instructed to bolus with PCA when VAS value was $\geq 4$. VAS values $\leq 3$ were accepted as sufficient analgesia levels.

\section{Cortisol and adrenocorticotropic hormone (ACTH) levels}

Blood samples were taken after blockage, 5 minutes before surgery, and at 5th and 60th minutes after start of surgery. Blood samples were centrifuged (MSE Mistral 3000E; ThermoLifeSciences, Crowley, 235 Sussex, UK) with $1500 \mathrm{rpm}$ at $20^{\circ} \mathrm{C}$ for 5 minutes right after they were collected. Samples were kept at $-20^{\circ} \mathrm{C}$ till they were analyzed. Cortisol levels were measured with Elecsys E170 auto analyzer (Roche, Mannheim, Germany) by using its own kits and electrochemiluminescence immunologic test. ACTH levels were measured with IMMULITE 1000 systems device (Siemens Healthcare Diagnostics, USA) by using its own kits and chemiluminescence immunologic test. Normal values were determined as 6.2-19.4 $\mu \mathrm{g} / \mathrm{dl}$ for cortisol and 20-65 pg/ml for ACTH.

\section{Other information}

Patients were evaluated for adverse effects that might develop during study (nausea, vomiting, rash, sedation, respiratory depression, hypotension, bradycardia, tachycardia, hematoma at injection area, infection and abdominal pain). $10 \mathrm{mg}$ IV metoclopramide was administered if nausea and gag reflex were present.

\section{Statistical analysis}

Statistical analysis was performed by using a standard statistics program (SPSS-15 (Chi, II., USA)). 
Descriptive statistics, frequency, percentage, mean, standard deviation, minimum and maximum are given. One-sample Kolmogorov-Smirnov test was used to evaluate whether data complied with distribution or not. Demographic data was evaluated by using Mann-Whitney $U$ and chi-square analysis. Repetitive measurements (VAS, categorical nausea score, sedation score, stress hormone levels) were evaluated with ANOVA variance analysis with Bonferroni correction and Mann- Whitney U test. The data were evaluated with $95 \%$ confidence interval. For all tests, $\mathrm{p}<0.05$ was accepted as statistically significant.

Power analysis showed that a sample size of 20 for each group will give a power of 0.80 at a level of significance of $=0.05$.

\section{Results}

This study on 70 patients between June 2009 - May 2010 was randomized. Hypotension occurred in one patient at FICB group, one in the 3 in 1 block group and two at control group and PCA treatment was stopped. For this reason, four cases were excluded from the study. For six cases (three from FICB group, and three from 3 in 1 block group) blockage could not reach desired success level. Thus, a total of ten cases were excluded (Figure 1).

There was no statistically significant difference between groups about demographic data of the patients (Table 1).

There was a statistically significant difference FICB

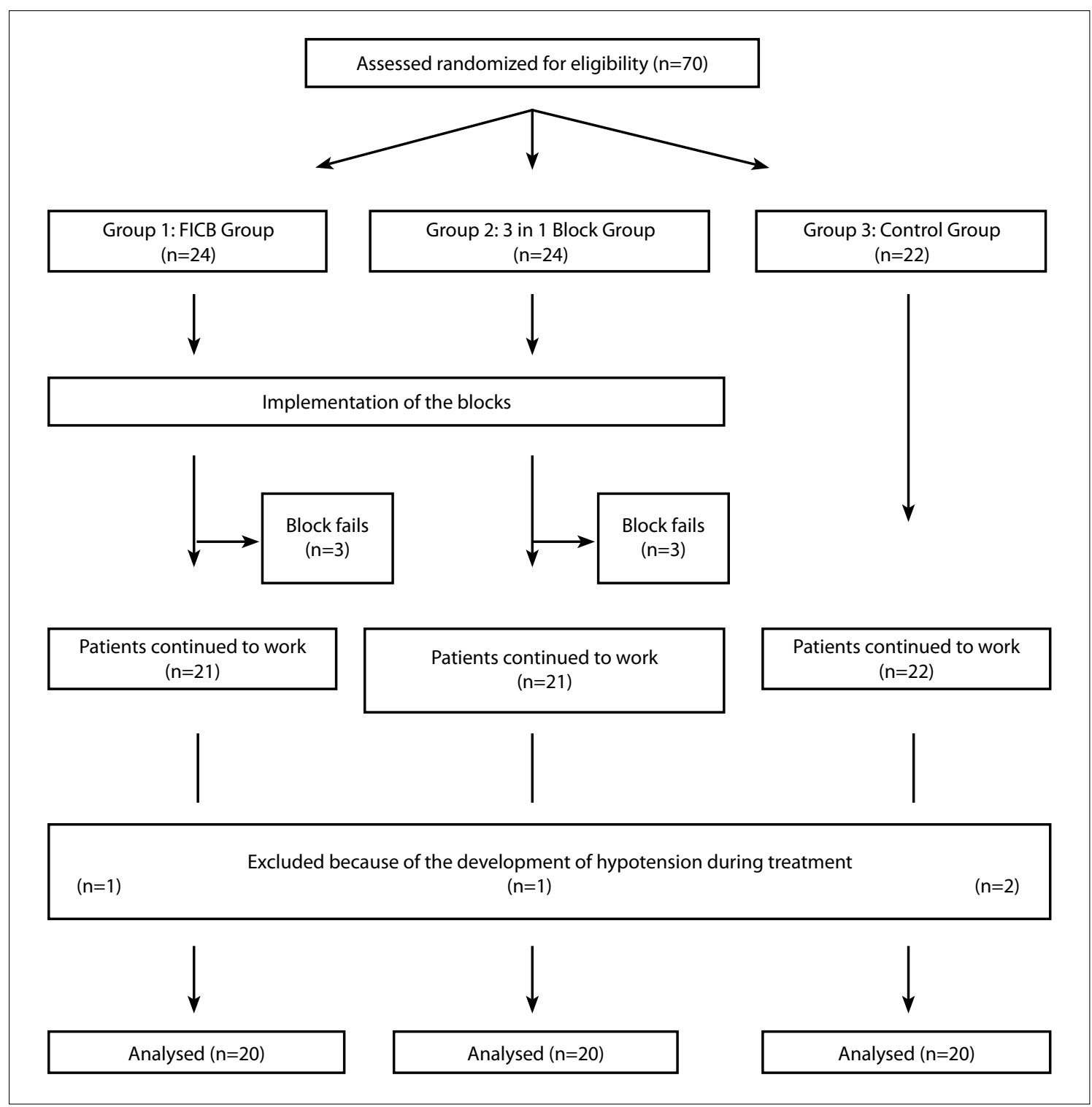

Figure 1. Trial profile (CONSORT Diagram). 
Table 1. Comparison of demographic data. Data is represented as \pm SD

\begin{tabular}{lcccc}
\hline Parameters & $\begin{array}{c}\text { FICB group } \\
\mathbf{n = 2 0}\end{array}$ & $\begin{array}{c}\mathbf{3} \text { in } \mathbf{1} \text { block group } \\
\mathbf{n = 2 0}\end{array}$ & $\begin{array}{c}\text { Control group } \\
\mathbf{n = 2 0}\end{array}$ & $\mathbf{p}$ \\
\hline Age (years) & $59.1 \pm 13.1$ & $67.8 \pm 10.1$ & $62.2 \pm 13.7$ & $>0.05$ \\
Gender (M/F) & $8 / 12$ & $11 / 9$ & $8 / 12$ & $>0.05$ \\
Size $(\mathrm{cm})$ & $165.8 \pm 10.1$ & $163.8 \pm 6.9$ & $162.8 \pm 9.3$ & $>0.05$ \\
Weigth $(\mathrm{kg})$ & $72.9 \pm 16.4$ & $72.5 \pm 11.0$ & $71.5 \pm 13.3$ & $>0.05$ \\
ASA $(\mathrm{I} / \mathrm{II} / \mathrm{III})$ & $12 / 6 / 2$ & $9 / 9 / 2$ & $5 / 10 / 5$ & $>0.05$ \\
\hline
\end{tabular}

and 3 in 1 block groups than control group when VAS values were compared only at 0 th and 2nd hours $(\mathrm{p}<0.05)$. However, there was no statistically significant difference between FICB group and 3 in 1 block group $(\mathrm{p}>0.05)$. No significant difference was found between each group about VAS values at 4th, 6th and 24th hours ( $\mathrm{p}>0.05)$ (Figure 2a).

There were no difference between groups about tramadol consumption at 0 th hour but tramadol consumption at $2 \mathrm{nd}$, 4th, 6th and 24th hours were significantly lower at FICB and 3 in 1 block groups than control group $(\mathrm{p}<0.05)$. Tramadol consumptions of FICB group and 3 in 1 block group at these hours were found statistically significant $(p>0.05)$ (Figure 2b).

While cortisol and ACTH levels of the patients were found statistically similar at 5 minutes before and 5 minutes after the surgery, they were found significantly lower at FICB group and 3 in 1 block group at postoperative 60th minute comparing to control group $(\mathrm{p}<0.05)$. However, cortisol and ACTH hormone levels of FICB group and 3 in 1 block group were similar at these hours $(\mathrm{p}>0.05)$ (Figure $2 \mathrm{c}, \mathrm{d}$ ).

There was no statistically significant difference between the groups about operation time, MAP, HR, nausea, sedation, additional analgesic and antiemetic.

There was not any complication that might be relevant to FICB in our study. In one case, prolonged (4 months) temporary motor and sensory neurologic deficit occurred due to 3 in 1 block.

\section{Discussion}

In our study, both block techniques decreased VAS
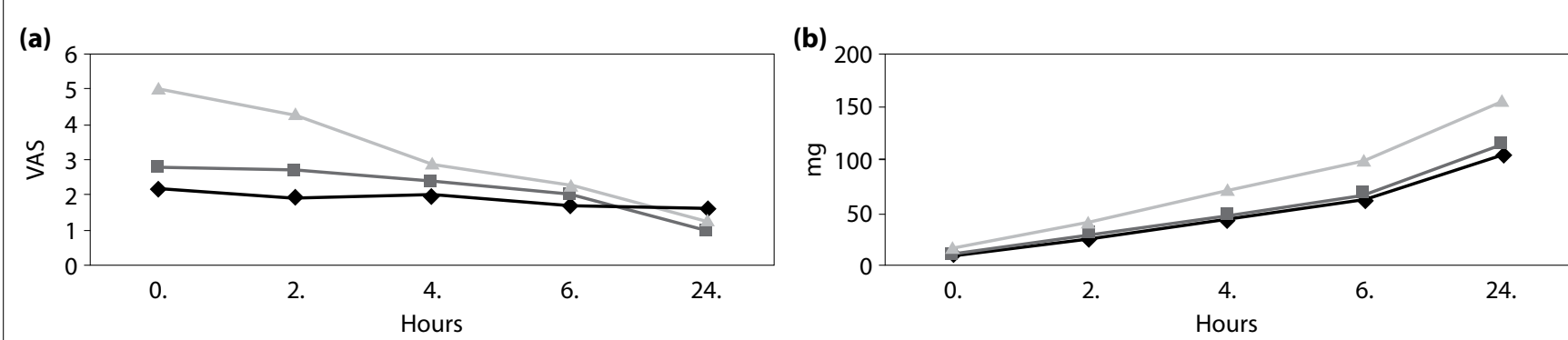

(c)

(d)
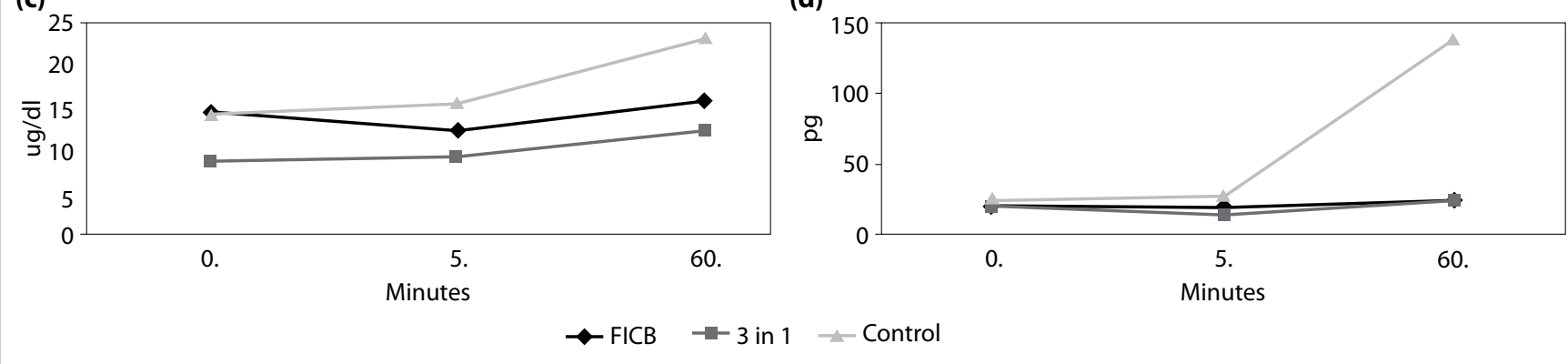

Figure 2. (a) Comparison of VAS values of groups. (b) Comparison of tramadol consumption of groups. (c) Comparison of cortisol hormone levels of groups. (d) Comparison of ACTH hormone levels of groups. 
scores at 0th and 2nd hours. No difference was found between the two treatment groups about their analgesic effects. Tramadol consumption was found decreased in block groups at 2nd, 4th, 6th and 24th hours comparing to control group. Tramadol consumption at the end of 24 hours was found $33.2 \%$ lesser at FICB group and $27.4 \%$ lesser at 3 in 1 block group comparing to control group. In both block groups stress hormone (cortisol and ACTH) levels found significantly lower at 60th minute comparing to control group. Except that data, demographic data, operation duration, hemodynamic data, additional analgesic and antiemetic need, and complications and adverse effects (i.e. nausea, sedation) were found similar in both groups.

The benefits of post-operative analgesia are clear. It decreases post-operative morbidity, improves results in some surgeries, facilitates rehabilitation and makes post-operative recovery shorter. ${ }^{[13,14]}$

Nowadays it is accepted that the best pain control at major surgeries like THP can be provided with multimodal or balanced analgesia. Thus, physicians see regional blocks, which are safe and easy, as effective methods for eliminating pain faster. ${ }^{[15,16]}$

The sensorial innervation of hip is provided by lumbar plexus and sacral plexus. Although whether lumbar or sacral plexus has primary effect on sensorial innervation of the hip remains unknown, according to some studies, lumbar plexus block can provide effective analgesia. ${ }^{[2,4]}$ Lumbar plexus femoral nerve block was first developed by Winnie et al. in 1973. ${ }^{[9]}$ 3 in 1 block is described as blocking femoral nerve, lateral cutaneous femoral nerve and obturatory nerve with an injection to inguinal ligament. ${ }^{[3,9]}$ However, this block does not reliably block the obturatory and lateral femoral cutaneous nerves and is now known as simply a femoral nerve block. Later Dalens et al. ${ }^{[5]}$ accidentally found FICB while trying to perform lateral femoral cutaneous nerve block. ${ }^{[3]}$ This procedure blocked the three stated nerves more successfully $(>90 \%)$ than 3-in-1 block. ${ }^{[2,3]}$ Neurostimulator are not needed in FICB procedure and it is felt to be safer because it is far to neurovascular structures. ${ }^{[2,3]}$

Capdevila et al. ${ }^{[4]}$ were able to block all three nerves that provide sensorial support of femur by perform- ing FICB and 3 in 1 blocks in only $35 \%$ of the cases. It is reported that success of femoral nerve blockage is high in FICB, but the success at blocking other two nerves, particularly obturatory nerve, is limited. [4] We were successful at 40 cases out of $46(87 \%)$. Our higher success levels comparing the literature may be relevant to the use of ultrasound. Swenson et al. ${ }^{[10,11]}$ performed FICB with ultrasound in 2006 and 2007 and then Dolan et al. ${ }^{[12]}$ performed it in 2008. In this study, ultrasound was compared with loss of resistance technique and block was found successful at $47 \%$ of loss of resistance group, and $82 \%$ of ultrasound group, respectively. ${ }^{[12]}$

For FICB, local anesthesia is dosed after the needle passes fascia lata and then fascia iliaca. With this technique, applying local anesthetic after resistance loss may be incorrect. With use of ultrasound it was revealed that there are multiple fascial planes at inguinal region. ${ }^{[12]}$

Stress response increases with surgical traumas. Application of nerve block for modifying endocrine and metabolic response is one of the most popular subjects recently because stress response is thought to be unnecessary at surgical approaches. Regional blockage techniques that are performed with local anesthetic agents prevent endocrine and metabolic response at pelvic and lower extremity surgeries. The increase at plasma concentrations of both hormones may be measured several minutes after the surgery starts. $^{[17]}$

\section{Conclusion}

We believe; the ultrasound guided 3 in 1 block and FICB are parts of multimodal analgesic treatment in order to enable postoperative analgesia in hip prosthesis surgery and these methods should be employed as a safe and efficient way.

\section{Acknowledgements}

Presented at the 43th Turkish Anaesthesiology and Reanimation Congress (October 1-November 1, 2010, Antalya, Turkey) and 6th World Congress of the World Institute for Pain, WIP 2012 (February 4-6, 2012, Miami, USA).

\footnotetext{
Conflict-of-interest issues regarding the authorship or article: None declared.
} 


\section{Peer-rewiew: Externally peer-reviewed.}

\section{References}

1. Høgh A, Dremstrup L, Jensen SS, Lindholt J. Fascia iliaca compartment block performed by junior registrars as a supplement to pre-operative analgesia for patients with hip fracture. Strategies Trauma Limb Reconstr 2008;3(2):65-70. CrossRef

2. Inan N, Akin Takmaz S, Iltar S, Yazici I, Başar H. The effects of two different multimodal analgesic regimens in total hip replacement surgery. Agri 2009;21(2):69-74.

3. Godoy Monzon D, Iserson KV, Vazquez JA. Single fascia iliaca compartment block for post-hip fracture pain relief. J Emerg Med 2007;32(3):257-62. CrossRef

4. Capdevila $X$, Biboulet $P$, Bouregba $M$, Barthelet $Y$, Rubenovitch J, d'Athis F. Comparison of the three-in-one and fascia iliaca compartment blocks in adults: clinical and radiographic analysis. Anesth Analg 1998;86:1039-44. CrossRef

5. Dalens B, Vanneuville G, Tanguy A. Comparison of the fascia iliaca compartment block with the 3-in-1 block in children. Anesth Analg 1989;69:705-13. CrossRef

6. Anker-Møller E, Spangsberg N, Dahl JB, Christensen EF, Schultz P, Carlsson P. Continuous blockade of the lumbar plexus after knee surgery: a comparison of the plasma concentrations and analgesic effect of bupivacaine $0.250 \%$ and 0.125\%. Acta Anaesthesiol Scand 1990;34(6):468-72. CrossRef

7. Matheny JM, Hanks GA, Rung GW, Blanda JB, Kalenak A. A comparison of patient-controlled analgesia and continuous lumbar plexus block after anterior cruciate ligament reconstruction. Arthroscopy 1993;9(1):87-90. CrossRef
8. Serpell MG, Millar FA, Thomson MF. Comparison of lumbar plexus block versus conventional opioid analgesia after total knee replacement. Anaesthesia 1991;46(4):275-7. CrossRef

9. Winnie AP, Ramamurthy $S$, Durrani Z. The inguinal paravascular technic of lumbar plexus anesthesia: the "3-in-1 block". Anesth Analg 1973;52(6):989-96. CrossRef

10. Swenson JD, Bay N, Loose E, Bankhead B, Davis J, Beals TC, et al. Outpatient management of continuous peripheral nerve catheters placed using ultrasound guidance: an experience in 620 patients. Anesth Analg 2006;103(6):1436-43. CrossRef

11. Swenson JD, Brown NA. Evaluation of a new fenestrated needle for ultrasound-guided fascia iliaca block. J Clin Anesth 2007;19(3):175-9. CrossRef

12. Dolan J, Williams A, Murney E, Smith M, Kenny GN. Ultrasound guided fascia iliaca block: a comparison with the loss of resistance technique. Reg Anesth Pain Med 2008;33(6):526-31.

13. Capdevila $X$, Barthelet $Y$, Biboulet $P$, Ryckwaert $Y$, Rubenovitch J, d'Athis F. Effects of perioperative analgesic technique on the surgical outcome and duration of rehabilitation after major knee surgery. Anesthesiology 1999;91(1):8-15. CrossRef

14. Kehlet $\mathrm{H}$, Holte K. Effect of postoperative analgesia on surgical outcome. Br J Anaesth 2001;87(1):62-72. CrossRef

15. Kehlet $H$, Rung GW, Callesen T. Postoperative opioid analgesia: time for a reconsideration? J Clin Anesth 1996;8(6):441-5.

16. Hanna MH, Elliott KM, Stuart-Taylor ME, Roberts DR, Buggy D, Arthurs GJ. Comparative study of analgesic efficacy and morphine-sparing effect of intramuscular dexketoprofen trometamol with ketoprofen or placebo after major orthopaedic surgery. Br J Clin Pharmacol 2003;55(2):126-33. CrossRef

17. Desborough JP. The stress response to trauma and surgery. Br J Anaesth 2000;85(1):109-17. CrossRef 